\title{
PEMBERDAYAAN MASYARAKAT DESA KERTAJAYA, CIANJUR OLEH PEMERINTAHAN DESA DAN PONDOK PESANTREN MIFTAHUL HUDA AL-MUSRI'
}

\author{
Asep Kurniawan \\ Staf Pengajar Institut Agama Islam Negeri Syekh Nurjati Cirebon \\ asepqurniawan.ak@gmail.com
}

\begin{abstract}
ABSTRAK
Peran pemerintah desa dan pesantren adalah sebagai lembaga pemberdaya masyarakat, Hal ini sebagaimana diperlihatkan dengan apa yang terjadi di Desa Kertajaya. Penelitian ini bertujuan untuk mengungkap secara mendalam tentang pemberdayaan masyarakat desa Kertajaya oleh pemerintah desa dan Pesantren Miftahul Huda. Metode penelitian ialah deskriptif kualitatif dan studi kasus. Instrumen pengumpulan data ialah wawancara mendalam, observasi mendalam, dan dokumentasi. Analisis data dilakukan melalui collecting data, reducing data, displaying data, dan conclusing data. Temuan penelitian menunjukkan bahwa Masyarakat Desa Kertajaya hidup rukun dalam keragaman agama. Mata pencaharian utama mereka adalah berpetani, namun memilliki kesejahteraan yang rendah. Untuk itu pemerintahan desa bersama lembaga yang ada khususnya Pesantren Miftahul Huda tergerak untuk melakukan pemberdayaan. Pemerintah desa mengadakan program pendidikan wajib belajar, pendidikan life skill, kesehatan, peningkatan pontensi pertanian bekerjasama dengan berbagai pihak. Sementara itu Pesantren Miftahul Huda al-Musri' selaku pesantren salaf yang memiliki keunggulan agrobisnis memberdayakan masyarakat melalui pendidikan keagamaan dan life skill, agrobisnis yang meliputi pertanian, perkebunan, peternakan, dan perikanan. Pemberdayaan masyarakat ini berdampak positif bagi peningkatan kesejahteraan masyarakat baik dalam tingkat pendidikan, spiritual maupun peningkatan pendapatan ekonomi.
\end{abstract}

Kata Kunci: Pengangguran, Urbanisasi, Kepedulian, Kearifan lokal, Perubahan keyakinan, Peningkatan Pendapatan

\begin{abstract}
The role of village government and pesantren are community empowerment institutions. This was shown by what happened in Kertajaya Village. This study aimed to reveal in depth the empowerment of the Kertajaya village community by the village government and Pesantren Miftahul Huda al-Musri'. The research method was one case qualitative-descriptive. Data collection
\end{abstract}


instruments were in-depth interviews, in-depth observations, and documentation. Data analysis was conducted through collecting data, reducing data, displaying data, and conclusing data. Research findings showen that the Kertajaya Village Community lived harmoniously in religious diversity. Their main livelihood was farming, but they had low welfare.For this reason, the village government together with the existing institutions,especially Miftahul Huda Islamic Boarding School were motivated to empower them. The village government organized compulsory education programs, life skills education, health, increased agricultural potential in collaboration with various parties. Meanwhile Pesantren Miftahul Huda al-Musri, a salaf pesantren, had the advantage of agribusines. It empowered people through religious and life skills education, agribusiness which included agriculture, plantations, livestock and fisheries. This community empowerment had a positive impact on improving the welfare of the community, both in the level of education, spiritual and increasing economic income.

Keywords: Unemployment, Urbanization, Concern, Local Wisdom, Changing Beliefs, Increasing Income

\section{A.Pendahuluan}

Peran sejumlah organisasi masyarakat Islam sangat penting dalam merealisasikan pengelolaan pemerintahan yang baik guna mewujudkan kesejahteraan bersama. Banyak organisasi masyarakatadalah kekuatan dari dalam pemberdayaan masyarakat sebagai salah satu aktor dalam pengelolaan pemerintahan. Dari banyak organisasi masyarakat ada yang berbasis keagamaan, yaitu salah satunyaialah pesantren.

Mengkaji peran pesantren dan keterkaitannya dengan upaya merealisasikan good governance dan pemberdayaan masyarakat menjadi suatu yang strategis dan penting. Disebut penting sebab untuk merealisasikan good governance diperlukan partisipasi aktifsetiap komponen governance dalam menciptakan kesejahteraan publik, termasuk dalam hal ini adalah peran pesantren sebagai bagian dari civil society. Dinilai strategis sebab pesantren tersebar di berbagai daerah di Tanah Air dan merupakan institusi yang tetap survive dan terbukti dapat melakukan banyak peran pemberdayaan masyarakat.

Pemberdayaan masyarakatberbasis pesantren sesungguhnya adalah upaya mencari jawaban dengan merespons tuntutan kebutuhan masyarakat. Di antara respon terhadap otonomi lembaga pendidikan yang adalah dampak dari desentralisasi 
pendidikan yang berwujud MBS (Manajemen Berbasis Sekolah) (Suharto, 2005: 325).Ide besar MBS hanya mereplikasi konsep dasar manajemen pendidikan yang diterapkan di Amerika (Danim, 2012: 26). Padahal nilai dasar MBS yang lebih memberikan ruang bagi peranaktif masyarakat dalam proses pendidikan telah menjadi bagian yang terintegrasi dalam sistem pen-didikan nasional. Misalnya, pondok pesantren, dipandang dalam sistem pendidikannya sudah mempunyai konsep yang sangat signifikan atas harapan ma-syarakat di sekitarnya (Suyata, 1996: 2). Eksistensi pesantren tidak bisa dilepaskan dari tuntutan dan kehidupan publik sebab pesantren dapat menjaga harmonisasi dengan masyarakat di sekitarnya sehingga keberadaannya sama sekali tidak terpinggirkan di tengah masyarakatnya. Hal ini menjadikan berbagai kegiatan pesantren memperoleh dukungan penuh dari mereka.

Pesantren sejauh ini sudah menerapkan manajemen berbasis masyarakat dalam aktivitas pelaksanaan pendidikan. Meskipun pesantren dari segi manajemen pendidikan, tidak mempunyai akar akademis yang mumpuni dalam manajemen pendidikan. Namun kenyataannya memperlihatkan pesantren sudah menjadi institusi pendidikan yang dapat hidup secara mandiri. Kemandirian itu tidak saja dalam konsep pendidikan untuk santri-santrinya, namun termasuk pada manajemen pesantren dalam pembiayaannya. Mastuhu menggambarkan dengan jelas bahwa pesantren mempunyai konsep pendanaan berapapun cukup (Mastuhu, 1994: 146).

Oleh karena itu, manajemen berbasis sekolah untuk sekolah negeri adalah pandangan yang baru, namun bagi pesantren bukan sesuatu yang baru lagi. Walaupun begitu, tidak ada banyak bukti yang memperlihatkan pesantren sudah menerapkan manajemen tersebut. Maka penelusuran secara mendalam mengenai pengelolaan pesantren berbasis masyarakat menjadi urgen diwujudkan sebab pesantren ini sama sekali belum tersentuh oleh program MBS yang digagas oleh pemerintah.

Pondok Pesantren Miftahul Huda al-Musri' Desa Kertajaya, Kecamatan Ciranjang, Cianjur Jawa Barat memiliki keunggulan dalam pemberdayaan sosial. Pesantren ini dalam perkembangan dan manajemennya berupaya memberdayakan masyarakat sekitar untuk menumbuhkan gerak ekonominya dalam lingkup unit-unit usaha pesantren. Pemberdayaan ini melalui potensi yang ada yang dimiliki oleh pesantren dan masyarakat yang umumnya bergerak di bidang pertanian, dan perikanan. Hal ini dikarenakan pengaruh pendiri pesantren yang sangat besar terhadap masyarakat di sekitarnya. Pesantren ini dipimpin oleh KH. Syaeful Uyuntelah meluluskan ribuan alumni dari 
banyak wilayah di tanah air, terutama daerah Jawa Barat. Keadaan ini tidak terlepas dari peran pesantren itu sendiri bagi perkembangan dan pemberdayaan masyarakat. Se-hingga eksistensi masyarakat sekitar dapat tertampung dan merasa mem-punyai tanggungjawab untuk senantiasa memajukan pesantren tersebut.Begitu pula dengan pemerintah Desa Kertajaya berperan memberdayakan masyarakat melalui sejumlah program yang ber-sinergi dengan berbagai lembaga yang ada.

\section{B. Landasan Teori}

Pemberdayaan masyarakat ialah proses pembangunan di mana masyarakat berinisiatif untuk memulai proses kegiatan sosial guna memperbaiki keadaan diri sendiri (James A. Christenson, Jerry W. Robinson. 1989) melalui pemanfaatan sumber-sumber yang ada pada mereka dan memfokuskan kepada prinsip peran aktifmasyarakat. Pemberdayaan masyarakat adalah suatu proses swadaya masyarakat yang di-maksudkan bagi peningkatan keadaan masyarakat pada bidang ekonomi, kultural, politik, dan sosial. Sebagai suatu metode, pemberdayaan masyarakat memfokuskan adanya proses peran aktif langsung dari masyarakat itu sendiri. Suatu upaya hanya berhasil dipandang sebagai pemberdayaan masyarakat jika kelompok masyarakat tersebut menjadi agen pembangunan atau disebut pula sebagai subjek. Di-sini subjek adalah bukan penerima manfaat, tetapi motor penggerak.

\section{Metode Penelitian}

Penelitian ini adalah penelitian kasus dengan pendekatan kualitatif deskriptif naturalistik. Peneliti berupaya melakukan riset secara mendalam terhadap kasus di Desa Kertajaya dan Pesantren Mitahul Huda al-Musri'yang dikaji yang dibatasi peristiwa, tempat, dan waktu tertentu. Penelitian kasus ialah salah satu metode penelitian dalam ilmu sosial.

1. Waktu dan Tempat Penelitian

Waktu penelitian ini ialah bulan November 2017 sampai dengan Juli 2018. Tempat penelitian ialah Pondok Pesantren Miftahul Huda al-Musri'dan Desa Kertajaya, Kecamatan Ciranjang, Kabuoaten Cianjur, Jawa Barat. Lokasi ini dipilih sebab Pondok Pesantren Miftahul Huda alMusri'ialah salah satu pondok pesantren di Cianjur yang berbasis agrobisnis dan sangat memfokuskan terhadap pemberdayaan masyarakat sekitar meskipun hakekatnya pesantren ini adalah pesantren salafiyah tradisional yang lazimnya menekankan pada sistem pendidikan pesantren tradisional.

2. Teknik Pengumpulan Data

Data yang dipergunakan adalah data primer dan data sekunder. Data primer diperoleh dengan triangulasi waktu, tempat, 
dan sumber. Instrumen pengumpulan data ialah observasi mendalam, wawancara mendalam dan dokumentasi. Data sekunder diperoleh dengan studi literatur.

Penetapan informan dengan memakai snowballing sampling, dan purposive sampling. Jumlah informan dalam studi ini ialah20 informan. Informan yang dimaksud ialah pimpinan pondok pesantren, aparat desa, tokoh masyarakat, kepala biro masingmasing unit yang menangani pemberdayaan masyarakat, santri, dan masyarakat binaan.

3. Teknik Analisis Data

Analisis data dilakukan di tempat penelitian yakni di Pondok Pesantren Miftahul Huda alMusri'dan Desa Kertajaya melalui cara menulis hasil wawancara ke dalam catatan harian. Selanjutnya peng-olahan data dilakukan ketika peneliti telah sampai Cirebon. Teknik analisis data dilakukan melalui matriks analisis data, yakni mengelompokkan atau mengategorikan data yang relevan.

\section{Temuan dan Pembahasan}

1. Deskripsi Umum Desa Kertajaya

Desa Kertajaya adalah desa yang berada di Kecamatan Ciranjang Kabupaten Cianjur, Provinsi Jawa Barat.

Penduduk Desa Kertajaya berjumlah 6.880 jiwa, yang terdiri dari 3.512 laki-laki dan 3.288 perempuan yang menempati luas 382,442 Ha. Masyarakat Desa Kertajaya adalah masyarakat majemuk dengan menganut agama yang beragam, yakni Kristen Protestan, dan Islam.

Level pendidikan masyarakat Desa Kertajaya adalah berpendidikan rendah. Mereka umumnya hanya lulusan Sekolah Tingkat Pertama. Penyebabnya ialah hambatan ekonomi masyarakat yang rendah pula dan masyarakat belum menilai bahwa pendidikan sebagai aset bagi kehidupan dan masa depannya.

2. Permasalahan Kesejahteraan Masyarakat Desa Kertajaya

Persoalan kesejahteraan masyarakat Desa Kertajaya dapat dilihat dari sisi mata pencahariannya. Desa Kertajaya adalah desa yang masih memiliki lahan pertanian produktif yang sangat luas. Hal ini dikarenakan daerah ini dan daerah lain di Kecamatan Ciranjang, Kabupaten Cianjur adalah daerah yang merupakan pusat lumbung padi di Provinsi Jawa Barat disamping Subang dan Karawang.

Desa Kertajaya adalah desa agraris, tetapi meskipun demikian se-bagian penduduk desa tidak sebagai petani pemilik lahan, namun hanya sebagai petani penggarap saja. Hal ini terjadi sebab kira-kira tahun 1982 pemerintah memiliki proyek pembangunan PLTA (Pembangkit 
Listrik Tenaga Air) di waduk Cirata sehingga masyarakat diminta untuk menjual lahannya kepada pemerintah dengan harga yang sudah ditetapkan oleh rezim Orde Baru yang ketika itu tengah memerintah. Penjualan tanah pertanian kepada pemerintah ini adalah titik permulaan petanipetani yang menjual tanah pertaniannya kepada orang-orang dari luar Desa Kertajaya.Kondisi ini masih berlangsung sampai saat ini yang berakibat kepada penguasaan tanah pertanian oleh penduduk Desa Kertajaya semakin menyempit. Mereka menjual tanah pertaniannya dengan alasan guna memenuhi kebutuhan sehari-hari dan juga untuk keperluan sekolah anak-anak mereka.

Tingkat pendidikan penduduk Desa Kertajaya masih rendah, dari informasi aparat pemerintahan desa dan dari data yang peneliti temukan terungkap bahwa masyarakat desa hanya dapat menyekolahkan anakanaknya pada tingkat sekolah menengah pertama bahkan masih ada masyarakatnya belum bisa menulis dan membaca.

Program-program yang diselenggarakan oleh aparat pemerintahan Desa Kertajayaadalah usaha pemberdayaan kelompok sosial ekonomi dengan skala kecil. Dengan pemberdayaan kelompok ini, masyarakat dapat meningkatkan kesejahteraannya. Hal ini terlihat dari jumlah pengangguran terbuka yang menurun, dari 250 orang menjadi 130 orang,peningkatan daya beli dan kesehatan masyarakat yang diperlihatkan dengan penambahan pendapatan sekitar Rp. 200.000 per hari. Kondisi ini berakibat ganda khususnya pada munculnya kesempatan pengembangan usaha ekonomi produktif.

Penduduk Desa Kertajaya mempunyai semangat gotongroyong yang sangat besar, hal ini terjadi sebab ikatan kekeluargaan yang sangat kuat tercipta antar masyarakat desa. Di samping itu keterkaitan pihak pemerintah desa dengan masyarakat desajuga terjalin dengan baik sehingga terbentuk sinergi yang kemudian mempermudah proses pembangunan desa. Hal ini adalah bentuk modal sosial yang dimiliki oleh penduduk Desa Kertajaya.

Penduduk Desa Kertajaya adalah penduduk yang senantiasa berubah sejalan dengan perkembangan zaman. Perilaku sosial masyarakat cenderung berubah kearah yang perilaku yang konsumtif, akan tetapi perubahan ini masih dalam batas kewajaran. Sejumlah anggota masyarakat Desa Kertajaya yang bekerja sebagai tenaga kerja di luar negeri di sektor informal, dan di kota-kota besar seperti Bandung dan Jakarta.

Aparat pemerintahan desa melakukan pembinaan terhadap 
para pemuda melalui kegiatan organisasi kepemudaan semisal karang taruna. Mereka memberikan pelatihan life skill, seperti keterampilan servis handphone, dan servis otomotif. Akan tetapi pelatihan ini dinilai belum memadai dan belum berhasil,sebab masih banyak pesertanya yang kurang serius sehingga kegiatan menjadi sia-sia. Pemuda Desa Kertajaya sekarang ini cenderung masih lebih senang mengisi waktunyadengan sesuatu kurang produktif seperti memancing atau nongkrong dijalan.

3. Aparat Pemerintahan Desa dalam Memberdayakan Masyarakat

Aparat pemerintahan desa membentuk sejumlah organisasi guna membantuk program pembangunan, khususnya dalam memberdayakan masyarakat. Pemerintahan desa ini mempunyai sejumlah organisasi, yaitu Koperasi Tani, Kelompok Tani, Karang Taruna, PKK, BPD, dan LPM. Berdasarkan informasi dari sejumlah aparat pemerintah desa setiap kelembagaan ini berjalan dengan baik dan lancar dalam melaksanakan program kerjanya. Koperasi tani dan kelompok tani berjalan secara mandiri tanpa adanya campur tangan dari aparat pemerintah desa.

Desa Kertajaya tidak mempunyai koperasi simpan pinjam bagi permodalan usaha masyarakat, namun masyarakat memiliki koperasi tani yang memberi bantuan berupa saprotan kepada anggota-anggotanya. Koperasi ini bekerjasama dengan Koperasi Karya Mekar Desa Sindangjaya meminjamkan permodalan. Anggota koperasi ini berasal dari empat desa di sekitar yakni Desa Gunungsari, Desa Kertajaya, Desa Sindangjaya, dan Desa Sindangsari. Target utama dari koperasi ini ialah penduduk dengan katagori hampir miskin, miskin, dan sangat miskin. Pinjaman modal berkisar antara Rp.500.000 sampai Rp.3.000.000 dengan jangka waktu pengembalian setidaknya satu bulan dan maksimalnya satu tahun.

Koperasi tani yang ada di Desa Kertajaya diantaranya ialah Koperasi Tani al-Musri', Koperasi Tani al-Furqon, dan Koperasi Tani Mina Cilandak. Koperasi-koperasi tersebut memberi pinjaman pada masyarakat berupa saprotan seperti alat-alat pertanian, benih, obatobatan, dan pupuk. Koperasi Tani al-Musri' dan Koperasi Tani alFurqon adalah koperasi taniyang didirikan oleh institusi keagamaan Islam sehingga anggotanya pun semuanya ialah umat Islam.

Desa Kertajaya mempunyai lima kelompok tani, hal ini sangatlah diperlukan sebagai wadah pemberdayaan masyarakat yang mayoritas bekerja sebagai petani. Kelompok tani ini, yaitu Tani Mukti, Babakan Curug, 
Mekar Saluyu, Itikurih, dan Bina Tani. Pada kelompok Tani Mukti di Desa Kertajaya beranggotakan gabungan antara orang-orang Islam dan orang-orang Kristen.

Lembaga keagamaan yang lain yang mendirikan koperasi ialah lembaga gereja yang menyelenggarakan program pemberdayaan masyarakat melalui kegiatan pada bidang pelayanan kesehatan, penyediaan pupuk, peti jenazah, dan pembuatan batako. Koperasi Kristen ini bernama Koperasi Kridapala yang berada di bawah organisasi Gereja Kristen Pasundan yang didirikan pada tahun 1995, akan tetapi keberadaaannya tidak bertahan lama, sebab didirikan oleh seorang mahasiswa yang melakukan riset di gereja tersebut dan saat mahasiswa tersebut merampungkan risetnya, maka koperasi tersebut tidak berjalan dan akhirnya bubar. Meskipun begitu sekarang ini pihak gereja mempunyai komisi yang berperan sama dengan koperasi.

4. Deskripsi Umum Pesantren Miftahul Huda al-Musri'

Pesantren Miftahul Huda alMusri adalah salah satu pesantren salaf yang memiliki keunggulan agrobisnis yang ada di Kabupaten Cianjur. Berdasarkan data Kementerian Agama Kabupaten Cianjur, ada tiga pesantren yang berbasis agrobisnis yakni Pesantren Nurussalam dan
Pesantren Martausshibyan terletak di kawasan Cianjur Selatan, serta Pesantren Miftahul Huda al-Musri' di Ciranjang.

Pondok Pesantren Miftahul Huda al-Musri' didirikan oleh Almarhum KH. Ahmad Fakih pada tahun 1957.Pesantren ini berlokasi di Kampung Pasirnangka, Desa Kertajaya, Kecamatan Ciranjang, Kabupaten Cianjur. KH. Ahmad Fakih ialah seorang alumni Pondok Pesantren Sukamanah Tasikmalaya, yang saat itu diasuh langsung oleh KH. Zaenal Mustofa. Beliau terkenal sebagai pahlawan nasional.

5. Pemberdayaan Masyarakat Kertajaya oleh Pesantren Miftahul Huda al-Musri'

a. Pemberdayaan Masyarakat melalui Pendidikan

Pondok Pesantren Miftahul Huda al-Musri'memberikan kontribusi dalam memberdayakan masyarakat sekitar melalui pendidikan. Pesantren adalah lembaga pendidikan keagamaan,akan tetapi pada sekarang ini Pondok Pesantren Miftahul Huda alMusri'telah menyelenggarakan bidang pendidikan umum, hal ini di-sokong oleh eksistensi program Kejar Paket A, paket B dan Paket $\mathrm{C}$ yang tidak saja untuk santri tetapi pula anak-anak putussekolah di Desa Kertajaya dan sekitarnya. Guru yang mengajar di setiap kelas ialah santri-santri senior yang mempunyai kemampuan baik 
dalam penguasaan metode pengajaran dan materi pelajaran.

Pesantren berpartisipasi dalam meningkatkan mutu pendidikan masyarakat Desa Kertajaya, hal ini ditunjukkan dengan adanya kemitraan antara pesantren dengan pihak pemerintahan desa dalam program peningkatan pendidikan masyarakat. Kerjasama ini bisa terjadisebab aparat pemerintah desa mengetahui bahwa pesantren mempunyai sarana dan prasarana pendidikan yang cukup seperti laboratorium komputer yang telah mempunyai jaringan internet dan gedung Wajib Belajar Pendidikan Dasar.

Upaya yang dilakukan oleh pesantren dalam pemberdayaan masyarakat dalam pendidikan ialah dengan melakukan program kemitraan dengan International Center for Islam and Pluralism (ICIP) yang dibantu oleh Ford Foundation menyelenggarakan Program Pendidikan Jarak Jauh Berbasis ICT-Information and Communications Technology (Teknologi Informasi dan Komunikasi). Tujuannya ialah untuk merealisasikan komunitas pesantren yang akrab dengan perkembangan teknologi komunikasi dan informasi bagi kemajuan peradaban Islam yang berorientasi ke depan, terbuka, humanis, inklusif, dan makin mengembangkan pesantren sebagai agent of changeyang bisa memberikan kemanfaatan bagi masyarakat sekitar.

b. Pemberdayaan Masyarakat dalam Ekonomi

Pemberdayaan ekonomi masyarakat oleh Pondok Pesantren Miftahul Huda al-Musri' diwujudkan melalui USP (Unit Simpan Pinjam) yang dikelola oleh Kopontren (Koperasi Pondok Pesantren) yang terbuka untuk masyarakat Desa Kertajaya. Akan tetapi target utamanya pemberdayaan ialah masyarakat yang telah mempunyai usaha ataupun masyarakat yang tidak mempunyai usaha, akan tetapi berkeinginan memiliki usaha. Pinjaman yang diberikan setidaknya Rp. 1000.000 dan paling besar berjumlah $\mathrm{Rp}$. 5.000.000. Tenggang waktu pembayaran paling lambat 3 tahun. Di samping sebagai usaha memperdayakan masyarakat dalam permodalan, hal ini juga dilakukan untuk menghindarkan masyarakat memijam modal kepada koperasi simpang pinjam milik organisasi Kristen yang ada di Desa Kertajaya. Dalam pemberdayaan ekonomi masyarakat, upaya yang dilakukan ialah dengan melakukan kemitraan dengan pihak luar, yaitu Bank Syariah Mandiri untuk lebih mempermudah pemberian kredit lunak bagi masyarakat.

c. Pemberdayaan Masyarakat melalui Agrobisnis 
Pesantren menetapkan bidang agrobisnis bagi pemberdayaan masyarakat Desa Kertajaya adalah untuk lebih memaksimalkan setiap potensi tersebut. Pesantren Miftahul Huda al-Musri' memilih pengembangan agrobisnis sebab berangkat dari pandangan bahwa semua keperluan masyarakat berasal dari pertanian. Berpijak dari pandangan ini, bahwa apabila manusia acapkali berinteraksi dengan tanah, maka akan cenderung berumur lebih panjang sebab manusia diciptakan dari tanah sehingga jika manusia lebih sering berhubungan dengan tanah yang merupakan asal mula kejadiannya.

Alasan lainnya adalah sebab Pondok Pesantren al-Musri'mempunyai tanah pertanian sekitar tujuh hektar, yang mesti didayagunakan bagi kepentingan masyarakat. Pesantren juga bekerjasama dengan PLN (Perusahaan Listrik Negara) yang berkaitan dengan lahan pertanian. Pesantren menyewa tanah yang tidak produktif milik PLN dengan biaya sewa sebesar Rp. 800.000 per tahun. Lahan ini di-pergunakan untuk perkebunan dan jugauntuk menanam pakan sapi.

Di samping itu, pihak pesantren merasa prihatin atas kondisi bangsa dan negara Indonesia yang dikenal sebagai negara agraris akan tetapi dikenal juga sebagai negara yang rawan pangan. Program pemerintah pemberdayaan dan penanggulangan kemiskinan yang sudah dilaksanakan oleh pemerintah, seperti pendampingan, pembangunan sarana dan prasarana umum, pemberian dana bergulir, pembangunan pertanian, pelayanan kesehatan dan pendidikan, dan penyediaan kebutuhan pangan, nampaknya belum banyak membuahkan hasil. Hal ini disebabkan kebijakan program-program tersebut lebih banyak bersifat top down (pemerintah pusat ke daerah). Kebijakan yang dimaksud memiliki sejumlah kelemahan yang harus dikoreksi secara mendasar (Bachtiar, 2007). Oleh sebab itu pesantren merasa harus untuk memulainya dari lingkungan mereka sendiri.

Dengan pemberdayaan masyarakat dalam bidang pertanian inilah diharapkan mengurangi laju urbanisasi masyarakat Desa Kertajaya untuk mencari pekerjaan ke kota. Masyarakat desa diberdayagunakan menggali dan mengoptimalkan potensi sumberdaya alam yang ada di desa. Sebab sejauh ini perkembangan ekonomi masihterpusat di kota, sehingga menarik minat masyarakat desa untuk senantiasa pergi ke kota untuk mencari kehidupan yang lebih baik.

Agrobisnis yang dimiliki oleh Pondok Pesantren Miftahul Huda al-Musri', yaitu: 
1) Pertanian sawah

Sekarang ini pertanian di Pondok Pesantren Miftahul Huda al-Musri' adalah pertanian padi sawah. Lahan sawah yang dimiliki oleh pesantren ini cukup luas sekitar 7 hektar dan letaknyajauh dari pesantren, terpencar-pencar atau tidak terpusat disatu tempat. Jenis padi yang ditanam ialah jenis Ciherang dan IR. Lahan pertanian sawah ini ada yang diolah oleh masyarakat, sasaran yang diprioritaskan ialah masyarakat kelas ekonomi menengah kebawah.

2) Perkebunan

Agrobisnis pesantren juga ada yang berupa perkebunan. Perkebunan tersebut dikelola oleh santri-santri. Mereka dipilih berdasarkan sifat keuletannya dan mempunyai pengetahuan dan keterampilan berkebun. Lahan yang digarap untuk perkebunan ialah sekitar 400 bata atau $5.600 \mathrm{~m}^{2}$.

Tanaman dalam perkebunan ini ialah kacang tanah, singkong, kedelai, dan tomat. Tanaman-tanaman tersebut ditanam dengan sistem tanam secara bergantian berdasarkan musim. Hasil dari perkebunan umumnya dipergunakan untuk memenuhi kebutuhansantri dan apabila ada kelebihan, maka dijual ke tengkulak. Sekali musim tanam tomatsaja, hasilnya bisa mencapai 1 ton.

Sekarang ini, dalam program perkebunan, pesantren masih lebih banyak melibatkan santri-santri dan melibatkan sejumlah kecil anggota masyarakat. Hal ini disebabkan lahan perkebunan yang dimiliki pesantren tidak begitu luas dan dengan alasan masih tersedia tenaga santri yang dapat dimaksimalkan.

3) Peternakan

Pesantren melakukan pemberdayaan melalui bidang peternakan. Peternakan yang dimaksud ialah peternakan bebek, domba, dan sapi. Dalam hal ini, pesantren melibatkan santri dan masyarakat. Mereka beternak sapi dan bebek di lingkungan pesantren. Mereka memberi pakan setiap hari, pagi dan sore dan mengganti air minum di siang hari. Dalam program pemberdayaan ini, mereka memiliki sekitar 200 ekor bebek.

4) Perikanan

Pesantren mempunyai dua jenis bidang perikanan, yakni kolam jaring apung (KJA) dan kolam darat. Latar belakang dibuatnya KJA adalah karena permintaan dari masyarakat yang berada di sekitar Desa Calingcing yang letaknya lebih dekat dengan waduk Cirata. Perikanan kolam darat diawali pada tahun 1999, sedangkan 
untuk KJA dirintis pada tahun 2006. Mereka adalah masyarakat yang telah menjadi konsumen tetap pesantren.

Pada awal jumlah KJA ini hanya beberapa petak, akan tetapi karena program ini terus mengalami kemajuan,sekarang ini KJA yang ada telah mencapai delapan petak dengan ukuran $6 \times 6 \mathrm{~m}^{2}$ per petaknya. Sedangkan perikanan kolam darat, program pemberdayaan inimempunyai 10 kolam yang tempatnya berdekatan dengan pesantren.

Jenis ikan yang dibudidayakan di kolam darat ialah ikan mas, nila, gurame, dan ikan lele. Sekarang ini sedang mencoba membudidayakan ikan bawal. Sementara itu, budidaya ikan di KJA ialah nila super blue dan ikan nila gif. Ikan nila super blue mempunyai keunggulan dibandingkan dengan ikan nila jenis yang lain, dikarenakan ukurannya yang lebih besar.

Para pembeli ikan di KJA dan kolam darat ialah masyarakat yang menggunakannya untuk memenuhi kebutuhan lauk pauk rumah tangga ataupun untuk membudidayakannya kembali. Masyarakat yang membeli untuk membudidayakan kembali umumnya membeli benih ikan dengan harga Rp.300.000 per liternya. Sedangkan untuk mereka yang membeli ikan bagi konsumsi rumah tangga, harganya ialah Rp.30.000 per kilonya.

Dalam rangka mensuksekan program pemberdayaan melalui perikanan ini, pesantren bekerjasama dengan pihak Balai Pengembangan Teknologi Perikanan (BPTP). Kerjasama ini dalam halteknologi jantanisasi ikan. Jantanisasi dilakukan supaya ukuran ikan yang dihasilkan bisa lebih besar.

Hasil pemberdayaan masyarakat melalui agrobisnis menggunakan:

1) Sistem bagi hasil, pada pertanian sawah pesantren memberdayakan masyarakat dengan melibatnya menggarap lahan sawah milik pesantren. Hasil pertanian yang dihasilkan akan dibagi sejalan dengan sistem syariah sehingga baik pesantren maupun masyarakat tidak merasa dirugikan. Bagi hasil inidilakukan sesudah dipotong oleh biaya produksi.

2) Sistem maro, pada pemberdayaan bidang peternakan, pesantren mempercayakan ternak yang dimiliki untuk dipelihara oleh masyarakat khususnya masyarakat dari kelas ekonomi menengah ke bawah. Contoh apabila kambing beranak dua maka bagi hasil 
antara satu untuk pesantren dan satu untuk masyarakat. Demikian pula seterusnya.

Pemberdayaan dengan cara seperti ini tujuannya adalah memaksimalkan potensi pesantren yang hidup di daerah pertanian, perkebunan dan perikanan. Pada gilirannya menjadikan pesantren sebagai agent perubahan bagi masyarakat.

d. Pemberdayaan masyarakat melalui program sosial keagamaan

$\begin{array}{llr}\quad \text { Dalam } & \text { hal ini } & \text { Pondok } \\ \text { Pesantren } & \text { al-Musri” } & \text { mem- } \\ \text { berdayakan } & \text { masyarakat } & \text { Desa }\end{array}$
Kertajaya melalui kegiatan-kegiatan sosial keagamaan yang dilakukan melalui pengajian-pengajian. Pengajian ini diselenggarakan secara rutin setiap minggu sebagai wujud pembinaan moral dan akhlak masyarakat desa. Pengajian adalah perkumpulan informal yang dimaksudkan untuk mengajarkan ajaran-ajaran agama pada masyarakat umum. Sehingga, pengajian sangat penting sekali sebagai gerakan islamisasi terhadap masyarakat (Horikoshi, 1987). Pada pengajian ini ustadz-ustadz menjelaskan dalil-dalil al-Qur'an lalu mengaitkannya dengan masalah-masalah kehidupan sehari-hari yang seringkali masyarakat temukan, seperti yang terikait dengan masalah keluarga, sosial kemasyarakatan, bahkan persoalan agrobisnis. Dalam pengajian ini menanyakan per- soalan tentang pemeliharaan hewan milik pesantren atau yang penggarapan lahan. Contoh mereka keperluan pupuktanaman atau pakan ternak, dan lain-lain.

Pemberdayaan masyarakat melalui program pengajian ini dilakukan dengan cara penyebaran santri-santri senior kepada semua mesjid dan mushola yang ada di Desa Kertajaya. Pengajian yang di selenggarakan di mesjid pesantren dilaksanakan setiap minggu. Pengajian bagi perempuan diadakan setiap hari Jum'at pagi dan pengajian untuk laki-laki diadakan setiap hari senin pagi. Pengajian bagi perempuan yang memberikan materi biasanya adalah para istri dewan kiai, sedangkan pengajian bagi laki-laki yang diadakan di mesjid pesantren biasanya diisi oleh dewan kiai.

e. Dampak Pemberdayaan Masyarakat terhadap Kesejahteraan

Pemberdayaan masyarakat oleh aparat pemerintah desa dan Pesantren Miftahul Huda al-Musri' telah memberikan peningkatan kepada banyak hal bagi kemajuan masyarakat itu sendiri pada bidang ekonomi dan pendidikan. Pemberdayaan masyarakat memberi dampak kepada peningkatan pendidikan masyarakat desa, hal ini karena pesantren memberi kesempatan pada santri yang berasal dari golongan menengah ke bawah dan tidak menuntut biaya pendidikan, pesantren juga mem- 
berikan keterampilan santri tersebut melalui bidang agrobisnis yang sedang dikembangkan karena mereka bekerja pada lahan pesantren setelah belajar.

Adanya program Wajar Dikdas dan fasilitas yang cukup memadai memungkinkan masyarakat untuk berusaha memperoleh pendidikan secara gratis dan akses internet yang terbuka sehingga menjadikannya lebih bisa terbuka kepada teknologi dan informasi.

Pemberdayaan masyarakat yang dilakukan melalui penyadaran di dalam pengajian dengan cara menyebar santri ke seluruh pelosok desa maupun pengajian rutin di mesjid pesantren lambat laun memberikan pengaruh terhadap perubahan perilaku kerja masyarakat desa. Para ustadz biasanya membacakan suatu ayat dalam al-Qur'an, hadist atau kitab kemudian menjelaskan kandungannya dan aplikasi terhadap kehidupan sehari-hari. Hal-hal yang diajarkan oleh ustadz-ustadz secara perlahan diaplikasikan oleh masyarakat desa dalam aktivitas kesehariannya.

Pengajian-pengajian ini juga membawa dampak (implikasi) pada akidah masyarakat yang beragama Nasrani di Desa Kertajaya. Tidak sedikit dari mereka yang memang dulunya beragama Islam namun akibat kegiatan kristenisasi kemudian memeluk agama Nasrani, namun kembali lagi memeluk agama Islam. Hal ini terjadi karena upaya pembinaan dan dakwah yang dilakukan oleh pesantren. Pesantren tidak pernah memaksakan kepada mereka yang beragama Nasrani untuk memeluk agama Islam. Hal tersebut merupakan kesadaran yang datang dari dalam diri mereka sendiri.

Ada sedikitnya 19 orang yang berstatus buruh tani yang diberi kesempatan oleh pesantren untuk memelihara kambing. Hampir sebagian besar berkembang biak dengan cukup signifikan. Ada yang dari 1 kambing menjadi 5 kambing, 3 menjadi 7 kambing, atau 3 menjadi 8 kambing. Sementara harga kambing jantan $1-2$ tahun saja saat ini dengan kondisi sedang bisa mencapai Rp. 3.300.000.Jumlah tersebut cukup untuk menambah modal usaha.

Dari hasil interview bahwa masyarakat mengaku rata-rata pendapatan mereka meningkat lebih dari $50 \%$ dari pendapatan semula. Misalnya, sebelum mendapatkan bantuan permodalan dari pesantren ada informan penelitian yang mengaku penghasilan mereka sebulan Rp. 800.000 meningkat menjadi Rp. 2.500.000.Setelah mendapatkan modal untuk mengembangkan usaha warung makan.

Implikasi penumbuhan 
budaya kerja ini, masyarakat desa tidak lagi terlalu terfokus untuk pergi ke kota mencari pekerjaan. Masyarakat desa diupayakan untuk menggali dan memaksimalkan potensi sumberdaya alam yang ada di desa itu sendiri. Walaupun secara umum, selama ini roda perekonomian masih banyak terpusat di kota sehingga menarik masyarakat desa untuk selalu datang ke kota untuk mencari peruntungan. Meminjam istilah dari pimpinan pesantren, roda perekonomian ibarat gula dan masyarakat adalah semutnya, selama gula tersebut masih terpusat di kota niscaya semut akan terus berusaha menggapai gula dengan cara datang ke kota. Namun jika gula tersebut tersedia di desa niscaya semut tidak perlu jauh untuk menggapai gula tersebut.

Pesantren saat ini sedang giat-giatnya membangun untuk kepentingan agribisnis dan juga sebagai tempat untuk menampung anak yatim. Ada sedikitnya 30 anak yatim yang ditanggung oleh pesantren Pembangunan ini menyerap tenaga kerja dari masyarakat sekitar sebagai buruh bangunan yang tentunya mereka bisa bekerja tanpa harus meninggalkan keluarga dan juga tanpa harus mengeluarkan uang makan dan transportasi karena tempat bekerja dekat dengan tempat tinggal. Bidang pekerjaan ini banyak digeluti oleh masyarakat di sekitar pesantren. Ada sekitar 24 petukangan dengan 81 buruh bangunan.

Unit Simpan Pinjam (USP) yang dikelola oleh Kopontren memungkinkan masyarakat memperoleh pinjaman modal tanpa bunga yang memberatkan. Masyarakat tidak di-bebani oleh bunga pinjaman yang dilarang oleh agama. Hal ini merupakan prinsipprinsip yang dipegang oleh pesantren menurut fiqih muamalah yang bersifat tsawabit (tetap), yaitu antara lain: tidak boleh melakukan kegiatan riba, tidak boleh ada unsur penipuan, dan tidak boleh saling menzalimi yang tercerminkan dalam prinsip bagi hasil.

f. Faktor pendukung dan penghambat pemberdayaan masyarakat

Terwujudnya pemberdayaan masyarakat oleh aparat pemerintahan desa dan Pesantren Miftahulhuda al-Musri' didukung oleh beberapa faktor, yaitu:

Pertama, kondisi geografis Desa Kertajaya yang berada di daerah pegunungan yang subur dan kaya akan air membantu terwujudnya pengembangan ekonomi dari sektor pertanian, perkebunan dan perikanan. Hal ini memudahkan optimalisasi sumber daya alam untuk meng-hasilkan pendapatan masyarakat dan pesantren.

Kedua, latar belakang masyarakat Desa Kertajaya yang 
umumnya adalah petani sejalan dengan program pemberdayaan untuk memanfaatkan potensi ini dalam bidang pertanian. Sumber Daya Manusia ini adalah faktor utama dalam kesuksesan pengembangan bidang ekonomi.

Ketiga, masyarakat dalam berbagai lapisan dari mulai aparatur pemerintahan desa sampai rakyat biasa masih menunjukkan kepedulian yang cukup bagi upaya pesantren dalam menjalankan program pemberdayaan bagi kesejahteraan masyarakat. Kepedulian tersebut diwujudkan seperti dalam pengelolaan pesantren, keikutsertaan dalam pengajian, dan pengolahan agrobisnis.

Keempat, faktor kepemimpinan kiai dan pemerintahan desa yang cukup disegani memberi andil besar bagi berjalannya program pemberdayaan. Sosok seorang pemimpin merupakan kunci sukses, karena dia adalah figur yang menggerakkan roda organisasi. Para santri dan masyarakat serta merta mengikuti arahannya dalam berbagai program pemberdayaan.

Sebagai pesantren tradisional (salaf), keputusan kiai masih sangat dijunjung tinggi, karena memang selama ini kiai memegang peranan yang sentral dalam setiap program yang dibuat. Apa yang dirancang kiai cukup visioner dan inovatif, contohnya pimpinan pondok pesantren saat ini memiliki rencana untuk lebih mengembangkan pesantren dengan cara pendirian pabrik pengolahan hasil pertanian mulai dari pabrik pengolahan daging ternak, pengolahan bio gas, pengolahan susu sampai pabrik pembuatan pupuk.

Selain sebagai decision maker pada setiap program yang disusun, pengaruh kiai tidak hanya di lingkungan pesantren saja namun juga di lingkungan sekitarnya hingga pada tingkat desa. Hal ini dikarenakan kiai sebagai pimpinan pesantren sangat aktif dan terlibat dalam pemerintahan desa, yang dibuktikan dengan jabatan yang dimiliki kiai selain sebagai pimpinan pondok pesantren juga merupakan wakil ketua Badan Pengawas Desa (BPD).

Selain faktor pendukung di atas, ada pula faktor penghambat pemberdayaan masyarakat. Terlepas dari manfaat yang dirasakan besar bagi masyarakat maupun pesantren sendiri dalam peningkatan kesejahteraan. Faktor penghambat tersebut antara lain:

Pertama, pesantren dan aparat pemerintah desa harus berusaha untuk hidup serasi dan harmonis dengan masyarakat sekitar. Sekalipun tidak jarang untuk mencapai maksud ter-sebut diawali oleh berbagai macam kendala sebab harus berusaha untuk perang nilai dengan masyarakat. Masyarakat desa banyak yang masih awam sehingga ketika 
akan dikenalkan dengan nilai-nilai Islam terkadang mereka bertahan untuk mencegah dan menghalanginya.

Kedua, kondisi masyarakat Desa Kertajaya yang sebagian besar bermata pencaharian sebagai buruh tani dengan pendapatan yang masih rendah menjadikan mereka hanya mampu menyekolahkan anaknya hanya pada tingkat Sekolah Menengah Pertama (SMP). Selain itu masyarakat juga belum mengutamakan pentingnya pendidikan bagi anak-anaknya. Mereka lebih suka anak-anak mereka bekerja keluar negeri dan menghasilkan uang banyak dari pada melanjutkan pendidikan.

Ketiga, masyarakat Desa Kertajaya merupakan masyarakat yang telah terbuka terhadap perubahan dari luar. Arus informasi yang begitu gencar dari berbagai media mengakibatkan masyarakat mudah menerima bahkan meniru informasi dari luar baik yang positif maupun negatif. Media menampilkan berbagai gaya hidup modern yang menjadikan masyarakat desa menjadi lebih sulit dibina. Gaya hidup yang ditampilkan oleh berbagai media massa lama-kelamaan mulai mengikis nilai-nilai yang ada pada masyarakat desa termasuk nilai-nilai pada segi keagamaan.

Keempat, akses terhadap teknologi yang kurang, dalam hal ini pemerintah desa, pesantren dan masyarakat belum memiliki teknologi yang layak untuk proses produksi maupun pengolahan hasil pertaniannya, seperti: traktor, alat pengering padi dan alat penggiling padi.

Kelima, akses terhadap modal yang kurang dalam hal ini masih banyak pihak bank masih yang enggan memberikan pinjaman jika digunakan sebagai modal mengembangkan agribisnis.

Keenam, akses terhadap distribusi, saat ini belum memiliki target pasar untuk produk yang dihasilkan. Sehingga produk hasil pertanian masih diorientasikan untuk pemenuhan kebutuhan internal.

Ketujuh, perhatian dari pihak yang berwenang dan terkait yang dinilai masih kurang. Pihak yang berwenang dalam hal ini adalah departemen pertanian dinilai belum memberikan dukungan baik moril apalagi materil yang memadai. Badan Penyuluh Pertanian (BPP) jarang memberikan penyuluhan kalaupun hal itu dilakukan semata-mata karena pihak pesantren dan masyarakat yang mengundang mereka.

Kedelapan, faktor harga komoditi pertanian yang tidak menentu juga menjadi alasan mengapa pesantren dan masyarakat belum terlalu mengutamakan hasil pertaniannya untuk dijual. 
Kesembilan, faktor alam dalam perikanan, adanya angin selatan yang bertiup pada bulan Desember sampai bulan Februari menyebabkan ikan enggan bertelur selain itu jika terjadi hujan yang terus menerus maka telur ikan enggan menetas. Hal ini menyebabkan produksi ikan cenderung menurun.

\section{E. Penutup}

Pemerintah desa dan pesantren berperan besar dalam pemberdayaan masyarakat untuk meningkatkan kesejahteraan mereka. Program pemberdayaan masyarakat ini dilakukan dengan memperhatikan potensi yang dimiliki desa dan pesantren serta kebutuhan dari masyarakat itu sendiri, sehingga pemberdayaan bisa berguna bagi masyarakat.Masyarakat Desa Kertajaya adalah masyarakat yang unik. Kondisi desa yang agraris, keragaman agama yang dianut, namun memiliki tingkat pendidikan yang rendah.

Pemberdayaan masyarakat dilakukan pada bidang sosial keagamaan, bidang pendidikan dan pelatihan. Sementara pemberdayaan pada bidang pertanian dilakukan melalui sistem maro dan sistem bagi hasil. Pemberdayaan pada bidang ekonomidilakukan melalui koperasi simpan pinjam dan kerjasama dengan Bank Syariah Mandiri.

Usaha pemberdayaan masyarakat menemukan sejumlah hambatan yang mengganggu program. Hambatan ini mulai dari kurangnya modal sampai keadaan alam yang tidak menentu. Hambatan yang dirasa sangat ber-pengaruh ialah kurangnya dukungan dari dinas yang terkait atas usaha pem-berdayaan masyarakat.

Ada sejumlah perubahan kesejahteraan kehidupan masyarakat ke arah yang lebih baik, contoh pada bidang ekonomi dan pertanian, masyarakat yang diberdayakan mengalami peningkatan income. Pada bidang pendidikan ber-dampak kepadamasyarakat kelas ekonomi bawah untuk dapat akses internet yang terbuka bagi masyarakat desa menjadikan masyarakat lebih dapat terbuka kepada teknologi dan mengenyam pendidikan secaragratis. Melalui pengembangan programpendidikan dan sarana prasarana yang cukup tersebut memungkinkan masyarakat desa mengalami peningkatan pengetahuan. Pemberdayaan melalui pengajian berdampak pada akidah masyarakat yang merupakan agama Nasrani. Banyak orang-orang Kristen di Desa Kertajaya yang memang sebelumnya beragama Islam, selanjutnya murtad memeluk agama Nasrani, namun kembali masuk agama Islam.

\section{DAFTAR PUSTAKA}

Abasri, "Sejarah dan Dinamika Lembaga-lembaga Pendidikan Islam di Nusantara", dalam Sejarah Pendidikan Islam, Menelusuri Jejak Sejarah 
Pendidikan Era Rasulullah Sampai

Indonesia. Editor Samsul Nizar. Jakarta: Kencana.

Adams, Robert. 2008. Empowerment, Participation and Social Work. New York: Palgrave Macmillan.

Adi, I.R. 2012. Intervensi Komunitas dan Pengembangan Masyarakat: Sebagai Upaya Pemberdayaan Masyarakat. Jakarta: Raja Grafindo Persada

Anwas, Oos M. 2013. Pemberdayaan Masyarakat di Era Global. Bandung: Alfabeta.

Bachtiar, Atok Maulana. 2007. Analisis Perubahan Penggunaan Lahan Di. Kecamatan Karanganyar Kabupaten Karanganyar Tahun 1998 dan Tahun 2003.Sarjana Surakarta: Fakultas Geografi UMS.

Christenson, James A., dan Jerry W. Robinson. 1989. Community Development in Perspective. Iowa City, Iowa: Iowa State University Press.

Cornell Empowerment Group. 1989. "Empowerment and Family Support", dalam Networking Bulletin, 1 (1) Oktober 1989: 2.

Danim, Sudarwan. 2012. Visi Baru Manajemen Sekolah: Dari Unit Birokrasi ke Lembaga Akademik. Jakarta: Bumi Aksara.
Flyvbjerg, Bent. 2006. "Five Misunderstandings About Case Study Research", dalam Qualitative Inquiry, vol. 12, no. 2, April 2006: 219-245.

Hamil, A.C.Stein. 2011. "Culture and Empowerment in the Deaf Community: an Analysis of Internet Weblogs", dalam Journal of Community and Applied Socail Psychology. vol. 21: 388-406.

Horikoshi, Hiroko. 1987. Kyai dan Perubahan Sosial. Perhimpunan Pengembangan Pesantren dan Masyarakat.

Mastuhu. 1994. Dinamika Sistem Pesantren. Jakarta: Gema Insani Press.

Mubyarto. 1993. Pengantar Ekonomi Pertanian. Jakarta: Penerbit LP3ES.

Muwahidah, Siti Sarah dan Zakiyudin Baidhowy (editor). 2007. Islam, Good Governance, dan Pengentasan Kemiskinan: Kebijakan Pemerintah, Kiprah Kelompok Islam, dan Potret Gerakan Inisiatif di Tingkat Lokal. Jakarta: MAARIF Institute for Culture and Humanity.

Ramos, A.M. dan Prideaux. 2014. "Indigenous Ecotourism in the Mayan Rainforest of Palenque: 
Empowerment

inSustainable

Issues

dalam Journal of Sustainable

Tourism. Vol. 22 (3): 461-379.

Rappaport, J. 1984. "Studies in Empowerment: Introduction to the Issue", dalam Prevention in Human Services, 3: 1-7.

Rowe, G. and Frewer, L.J. 2005. A Typology of Public Engagement Mechanisms", dalam Science, Technology, and Human Values, 30 (2), April 2005: 251-290.

Soekanto, Soerjono. 2010. Sosiologi Suatu Pengantar. Jakarta: Rajawali Pers.

Syahyuti. 2006. 30 Konsep Penting dalam Pembangunan Pedesaan dan Pertanian: Penjelasan tentang Konsep, Istilah, Teori, dan Indikator serta Variabel. Jakarta Selatan: Bina Rena Pariwara.

Suharto, Toto, 2005. "Konsep Dasar Pendidikan Berbasis Masyarakat", dalam Cakrawala Pendidikan, XXIV, No. 3, November, 2005.

Suyata. 1996. Community Participation in School Development: Acces, Demand, and School Construction. Jakarta: Directorate of Seconday Education, Directorate General of Primay and Secondary Education, Ministry of Education and Culture.
Zimmerman,

M.A.

2000.

"Empowerment Theory:

Psychological, Organizational and Community Levels of Analysis", dalam Handbook of Community Psychology, 43-63. 